\title{
Core Model on Improving Mathematical Communication and Connection, Analysis of Students' Mathematical Disposition
}

\section{R. Poppy Yaniawati}

Prof., Universitas Pasundan, Indonesia, pyaniawati@unpas.ac.id

\section{Rully Indrawan}

Prof., Universitas Pasundan, Indonesia, rully.indrawan@unpas.ac.id

\section{Gita Setiawan}

M.Pd, Universitas Pasundan, Indonesia, tagita_gita20@yahoo.com

$$
\mid
$$

This study aimed to improve of mathematical communication, mathematical connection and analyze mathematical dispositions of students by using the CORE (Connecting-Organizing-Reflecting-Extending) learning model. The study applied a mixed method with embedded design. The subject were $82 \mathrm{X}$ grade students of high school in Sukabumi, West Java, Indonesia. It divided into 42 students for the experimental group and 40 students for the control group. The research data were obtained through well-structured tests of mathematical communication and mathematical connection, mathematical disposition questionnaires, observation sheets, and interviews. Data analysis used t-test, correlation test, descriptive statistic and qualitative. The results indicated that; 1) the CORE learning model can improve students' mathematical communication and connection skills, 2) the mathematical communication for topic $\mathrm{I}=76.46$; topic $\mathrm{II}=70.98$; topic $\mathrm{III}=72.87$; post-test=74.26; and the mathematical connection for topic $\mathrm{I}=80.07$; topic $\mathrm{II}=79.98$; topic $\mathrm{III}=75.78$; post-test $=80.27$; 3) mathematical communication and connections of students who learned with the CORE model was better than those used expository learning, 4) mathematical dispositions of students who learned with the CORE model was higher than those used expository learning as well and 5) there were correlation among mathematical communication, mathematical connection and mathematical dispositions.

Keywords: CORE model, mathematical communication, mathematical connection, mathematical disposition, mixed method

Citation: Yaniawati, R. P., Indrawan, R., \& Setiawan, G. (2019). Core Model on Improving Mathematical Communication and Connection, Analysis of Students' Mathematical Disposition. International Journal of Instruction, 12(4), 639-654. https://doi.org/10.29333/iji.2019.12441a 


\section{INTRODUCTION}

Mathematics is a science that underlies the development of modern technology in education in Indonesia. It has an important role in various disciplines and develops human thinking power. Mathematics contributes to the development of the ability to think critically, systematically, logically and the ability to work together effectively. One of the learning goals according to Depdiknas (2008) is to communicate ideas with symbols, tables, diagrams or other media. Thus, mathematical communication skills are very important for every student. Kosko \& Gao (2015) show that the main implication of his research is that the authors of policy documents must pay attention to how languages that support communication are used in content standards. Thus, mathematical communication skills are abilities that are very important for students, because they can affect many things, including in everyday life.

Besides the students' communication skills that need to be developed, also the mathematical connection skills need to be trained. Hariwijaya (Fajri \& Ikhsan, 2013) states that the ability of connection and communication skills need to be trained for all students in the school, even mathematics learning will be more meaningful with an emphasis on the interrelationship between mathematical concepts in daily life. Yaniawati, Kartasasmita, Kariadinata \& Sari (2017) states that students 'mathematical connection skills play an important role in solving problems, then this has a positive impact on students' self-regulated learning.

In addition to cognitive aspects, there are affective aspects of the purpose of mathematics learning. Affective aspects involve values of appreciating the usefulness of mathematics in life, which includes having curiosity, attention, and interest in learning mathematics. These attitudes and habits will essentially foster mathematical dispositions. According to Kilpatrik (2001), the mathematical disposition of students is a major factor in determining success in their education. Mathematical disposition will be seen when students work on mathematical questions, whether done with confidence, responsibility, diligent, unyielding, feeling challenged, having the willingness to look for other ways and reflecting on the way of thinking that has been done. NCTM (2000) suggested that mathematical dispositions show self-confidence, expectations and meta cognition, serious passion and attention in learning mathematics, persistence in dealing with and solving problems, high curiosity, and the ability to share opinions with others. Besides, Polking (Sumarmo, 2010) stated that mathematical disposition namely desire, awareness, tendency and strong dedication to students or colleague students to think and do mathematics positively. Disposition is very important as a provision in the development of mathematical abilities, such as the opinion of Gabriel, Signolet \& Westwell (2017) that dispositions can have an influence on mathematical literacy.

According to Ghanizadeh \& Royaei (Roshandel, 2018) teachers are advised to consider student attitudes, feelings, and values regarding learning so that they are not included in the experience of failure and lack of motivation. Hence, a learning model is needed that can foster mathematical communication and connection skills. To realize that these expectations can be achieved, one of the learning models in question is the ConnectingOrganizing-Reflecting-Extending (CORE) learning model. This is in line Risnawati, 
Khairinnisa \& Darwis (2018) who reported her results of research that linear algebra lectures using the CORE model based on student worksheets with reading assignments, could facilitate students' mathematical communication skills. Students began to get used to doing mathematical modeling eventhough there were still some errors in the resolution algorithm.

According to Calfee (2010), the Connecting-Organizing-Reflecting-Extending (CORE) learning model is a discussion model that can influence the development of knowledge and reflective thinking that has the teaching stages of Connecting, Organizing, Reflecting and Extending. The syntax of the connecting-organizing-reflecting-extending learning model includes: (C) the connection of old-new information and between concepts, (O) organizational ideas to comprehend the material, (R) rethinking, exploring, and digging, (E) developing, expand, use, and find. Research of Risnawati, Khairinnisa \& Darwis (2018) shows that the CORE model-based worksheet with recitation task in linear algebra can increase student activity in the learning process and students' mathematical communication skills in the high category. However, the research is a development research that does not compare with conventional classes.

Based on the problems described, the purpose of this study is to improve the capability of mathematical communication skills, mathematical connections and analyze the mathematical dispositions of students who receive the CORE model learning and students taught with conventional learning who use the expository method, as well as to anayze the relationship among mathematical communication skills, mathematical connecsions and mathematical dispositions of students.

\section{LITERATURE REVIEW}

\section{The CORE Learning Model}

CORE stands for four words that have a unity of functions in the learning process, namely Connecting, Organizing, Reflecting, and Extending. According to Harmsen (Humaira, 2014), these elements are used to connect between old and new information, organize a number of varied materials, reflect everything that students learn, and develop a learning environment. Another opinion from Fisher, Yaniawati \& Kusumah (2017) is that CORE is one of the learning models based on constructivism theory that students should be able to construct their knowledge, through self-interaction with their environment.

Calfee (2010) revealed that the CORE model is a learning model using discussion methods that can influence the development of knowledge and reflective thinking by involving students who have four teaching stages namely Connecting, Organizing, Reflecting, and Extending. Calfee (2010) also revealed that what is meant by CORE model learning is a learning model that expects students to be able to construct their own knowledge by connecting and organizing new knowledge with old knowledge then rethinking the concept being studied (Reflecting) and students are expected to expand their knowledge during the teaching and learning process (Extending). Table 1 shows the CORE model and descriptions of each step. 
Table 1

CORE Model and Descriptions of Each Step

\begin{tabular}{ll}
\hline CORE & Description \\
\hline Connecting & $\begin{array}{l}\text { Teachers activate previous knowledge by asking students to actively reflect, } \\
\text { share with other friends, and write from their knowledge and experience. The } \\
\text { teacher guides students to associate material that they already known by } \\
\text { students to find out new material. The practice can be in the form of } \\
\text { observing and recalling old information related to new information that } \\
\text { implemented through group discussions. }\end{array}$ \\
\hline Organizing & $\begin{array}{l}\text { Students organize ideas to understand the material. The practice can be in the } \\
\text { form of activities compiling steps in formulating conclusions from new } \\
\text { information that discussed in the group. }\end{array}$ \\
\hline Reflecting & $\begin{array}{l}\text { Student is reflecting ways of thinking about what student has just learned or } \\
\text { thinking back about what has been done regarding learning in the past. }\end{array}$ \\
\hline Extending & $\begin{array}{l}\text { Opportunities for students to synthesize their knowledge, organize it in new } \\
\text { ways and turn it into a new application. }\end{array}$ \\
\hline
\end{tabular}

\section{Mathematical Communication and Connection}

NCTM (2000) states that the standards for mathematics learning processes are: problem-solving, reasoning and proof, communication in mathematics, interrelationships in mathematics (connection) and representation. These capabilities can support and complement each other. Kosko \& Gao (2015) stated that the importance of mathematics as communication was noted in early drafts, but mostly in the context of the growing need for mathematical literacy in the postindustrial age. Whereas, Hiebert and Carpenter (Zengin, 2019) described mathematical connections, which are necessary and fundamental for the development of mathematical understanding, as part of a network structured as a spider's web.

NCTM (2000) suggests that students can learn mathematics as a communication tool so students must be able to: (a) model situations using oral, written, concrete; images, graphics, and algebraic methods; (b) think and explain their own thoughts about mathematical ideas and situations; (c) develop a general understanding of mathematical ideas, including the role of definitions; (d) use reading, listening, and seeing skills to interpret, and evaluate mathematical ideas; (e) discuss mathematical ideas and make assumptions and reasons that are convincing, and; (f) appreciate the value of mathematical notation and its role in the development of mathematical ideas.

Indicators of mathematical connection ability according to NCTM (2000) are namely: (a) recognizing and using relationships between ideas in mathematics; (b) understanding the relevance of mathematical ideas and forming ideas with one another so as to produce a comprehensive relationship; (c) identify and apply mathematically inside and outside the mathematical environment. In line with this, Sumarmo (2012) presents several indicators of students' mathematical connection abilities, including (a) understanding the relationship of various representations of mathematical concepts and procedures; (b) looking for relationships of various representations of mathematical concepts and procedures; (c) understanding between mathematical topics; (d) applying mathematics in other fields or in daily life; (e) looking for the relationship of one other procedure in 
equivalent representation; (f) applying relationships between mathematical topics and between mathematical topics and topics outside mathematics.

\section{Mathematical Disposition}

Pearson Education (2000) states that mathematical dispositions include a genuine interest in learning mathematics, persistence in finding solutions to problems, willingness to find alternative solutions or strategies and appreciation of mathematics and its application in various fields. The disposition indicators in this study include: (1) confidence in mathematical abilities possessed, (2) collaboration / sharing knowledge, respecting different opinions, trying to find other solutions / strategies in solving mathematical problems, (3) persistent, diligent, attention and sincerity, (4) enthusiasm / enthusiasm in learning, (5) Setting targets to be achieved, evaluating assignments, (6) assessing the practice of mathematics to other situations in mathematics and daily experience and (7) appreciation the role of mathematics in culture and value, mathematics as a tool, and as a language.

Some other opinions about mathematical dispositions, namely: Wasicko (Brewer, 2011) states that even though there have been many definitions of dispositions, the dispositions of qualities are characteristic of an effective when they are determined, we must evaluate what we will assess. Thus, the disposition is not only a student's attitude towards something, but further than that is how we can evaluate from what they have done. National Research Council (2001) mention mathematical dispositions as productive disposition, namely the view of mathematics as something logical, and produce something useful. Similar to Polking's opinion (Sumarmo, 2010), they specified the mathematical disposition indicators as follows: showing passion in learning mathematics, showing serious attention in learning, showing persistence in facing problems, showing self-confidence in learning and solving problems, showing high curiosity, and the ability to share with others.

\section{METHOD}

\section{Model and Design}

This study uses a mixed method with embedded design. The quasi-experiment with control class which is used in this research is non-equivalent [pretest and post-test] Control-Group Design (Indrawan \& Yaniawati, 2014) as follows:

\section{Group A: O X O}

Group B: O O

In such design, $\mathrm{X}=\mathrm{CORE}$ model, $\mathrm{O}=$ Test of Mathematical Connection and Communication, group A is an experimental class, and group B is a controlling class. This is in line with the results of Pekrun, Goetz, Titz \& Perry (2010) study which shows that mixed methods have proven advantages that can help solve the complexities of affective variables in real life, not just rely on qualitative or quantitative strategies. 


\section{Subjects}

The numbers of subjects in this study were 80 grades $\mathrm{X}$ students of SMAN 1 Parungkuda, in Sukabumi, West Java, Indonesia. The experimental class consisted of 42 students whose communication skills and mathematical connections were still low, while a control class consisted of 40 students. Implementation and data collection that occurred at the school were for nine meetings. The materials discussed during the research are (1) sine rules, (2) cosine rules and (3) triangle area.

\section{Data Collection}

The research data were obtained from tests of mathematical communication and connection skills to see the improvement of students' mathematical communication and connections skills, mathematical disposition questionnaires to see students' mathematical dispositions, observation sheets to look at mathematical dispositions qualitatively and implementation of CORE learning, and interviews to find out more about students' mathematical dispositions. Researchers conducted efforts to improve communication skills and mathematical connections on trigonometric material through the CORE learning model. All of the instruments have been developed by the researchers and tried out to fulfill the requirements of qualified validity and reliability.

\section{Test of mathematical communication and connection ability (MComA and $\operatorname{MConA)}$}

Mathematical connections and communication skills were measured by tests. To measure these two abilities two tests were carried out, each of which were the six main aspects according to indicators of communication skills and mathematical connections. The connection rating system was mathematically adjusted for the complexity and achievement of each question. Questions about tests of mathematical connection skills consist of 6 questions. Questions number 1 to 4 had scores of 0 to 5, while questions number 5 had scores of 0 to 10 and question number 6 had score of 0 to 20 . So, the ideal maximum score was 50 . The validity coefficients obtained from each item range from $0.40-0.85$ (sufficient, medium and high) and the reliability coefficient was 0.70 (high). In addition to the test questions, mathematical communication skills consisted of 6 questions. Questions 1,2,4 and 5 had scores of 0 to 10 , while questions number 3 and 6 had scores of 0 to 5 . So, the ideal maximum score was 50 . The validity coefficients obtained from each item ranged from $0.61-0.86$ (high) and the reliability coefficient was 0.84 (high).

\section{Mathematical disposition scale (MD)}

Mathematical disposition of students was measured using a Likert scale model. The scale contains: statements according to indicators of mathematical disposition aspects: (1) controlling and monitoring (planning goals, managing, monitoring, and evaluating learning processes and results), (2) motivation (interest, effort, perseverance, selfefficacy), and (3) behavior (utilizing the environment to optimize learning). The discriminatory power coefficient $(\mathrm{T})$ items ranged from 1.85 to 6.77 (tab $=1.76$ ), and the reliability coefficient was 0.90 (high). 


\section{Implementation of CORE and Procedure of the Research}

In the CORE model learning process, students were required to be more active and creative, they were accustomed to being more open to accepting different opinions from friends. Students were asked to study in groups and gave input to other friends. Then students presented the results of their work in front of the class, while other groups were asked to respond.

However, in solving mathematical problems students were still fixated on one way of solving, students still were afraid of expressing new ideas. Nevertheless, students began to try to solve some mathematical communication problems and mathematical connections in their own ways and expressions. While students in expository learning had not been able to express new ideas at all, they solved problems in a manner similar to the example of the teacher.

Students with CORE learning were positive towards mathematics, almost all students showed tendency to never avoid math, students enthusiastically participate in learning. Students showed good curiosity.

Measurement of communication skills and mathematical connections of students was done twice as much, namely before and after the learning process. The initial measurement, called the pre-test, aimed to see the equality of the initial abilities of the two groups. The final measurement called post-test was carried out after the two groups had studied with different treatments. This test aimed find out how the impact of learning was given to students' communication and mathematical skills.

This study consisted of three cycles in which each cycle was carried out during two meetings. At the end of the cycle a test (quiz) was given for each different topic. The learning process of each cycle was in accordance with the improvement of the results of reflections made in the previous cycle. Reflections were obtained from the results of observations and tests on each topic of material. In this study, each cycle was given a different topic of continuous material.

\section{Data Analysis}

Data analysis for mixed method research used quantitative and qualitative data. Quantitative data from pre-test, post-test, and N-gain, the normality and homogeneity of variance were tested. Normality test of the data used the Kolmogorov-Smirnov test and the variance homogeneity test of two data used the F-test. Data that was normally distributed used parametric inferential tests using the T-test. To analyze the correlation between variables using the product moment-test. While data that was not normally distributed used a non-parametric test, namely the Mann-Whitney U test. The statistical analysis used in this study was a test with a significance level of 0.05 for quantitative data. For qualitative data, triangulation was used through questionnaires, interviews with students and observation of the learning process. 


\section{FINDINGS}

From the research that has been done, data obtained included data from the results of tests of communication skills and mathematical connections from each cycle. The following are results of the test of mathematical communication ability and mathematical connection ability of topic I, topic II, topic III and post-test.

Table 2

Average Mathematical Communication Ability Test Results

\begin{tabular}{clllll}
\hline Average & MCC & Topic I & Topic II & Topic III & Post Test \\
\cline { 2 - 6 } & 70 & 76.46 & 70.98 & 72.87 & 74.26 \\
\hline
\end{tabular}

Note: $\mathrm{MCC}=$ minimal completeness criteria

Also, for students' mathematical communication skills test results for topic I the average values was 73.40; topic II had an average score of 70.98; topic III had an average score of 72.87 and the post-test had an average value of 74.27. All of these values were compared to the established MCC.

Based on data analysis, it was found that the N-gain control class obtained a Sig = 0.200 > value of $\alpha=0.05$, thus the data was normally distributed. While the $\mathrm{N}$-gain data for the experimental class obtained a Sig $=0,006<$ of $\alpha=0.05$, thus the data was not normally distributed. Thus, testing the difference in the two means using a nonparametric test, namely using Mann-Whitney $\mathrm{U}$ as shown in table 3.

Table 3

The Two Mean Difference for Test of Communication Ability

\begin{tabular}{ll}
\hline Test Statistics $^{\mathrm{a}}$ & \\
\hline & Mathematical Communication \\
\hline Mann-Whitney U & 195.500 \\
\hline Wilcoxon W & 861.500 \\
\hline$Z$ & -5.202 \\
\hline Asymp. Sig. (2-tailed) & .000 \\
\hline
\end{tabular}

From the results of the Mann-Whitney Test in Table 3, the Sig (2-tailed) $=0,000<\alpha=$ 0.05 value means that $\mathrm{H} 0$ is rejected. Thus, there is a difference in the increase in students' mathematical communication skills using CORE learning models with students who obtain expository learning.

Thus, it can be concluded that the increase in mathematical communication skills of students who get learning with the CORE learning model is better than increase of mathematical communication skills of students who had the expository method.

Table 4

Average Mathematical Connection Ability Test Results

\begin{tabular}{llllll}
\hline Average & MCC & Topic I & Topic II & Topic III & Post Test \\
\cline { 2 - 5 } & 70 & 80.07 & 79.98 & 75.78 & 80.27 \\
\hline
\end{tabular}

Note: $\mathrm{MCC}=$ minimal completeness criteria 
Table 4 explains that for mathematical connection abilities students test results of topic I get an average value of 80.07 ; topic II get an average value of 79.98 ; topic III get an average value of 75.78 and post-test get a value average of 80.27 . Therefore, the results explain that mathematics learning using the CORE learning model can improve students' mathematical connection skills, namely increasing the initial data by 60 to 80,27 in the post-test.

Based on data analysis using Kolmogorov-Smirnov, it was found that the N-gain of the control class had a Sig $=0.200>$ value of $\alpha=0.05$, and the experimental class N-gain data had a Sig $=0.200>$ value of $\alpha=0.05$; thus the second the data group was normally distributed. Thus, the data n-gain connection ability for the control class and experiment was normally distributed.

Whereas the results of the homogeneity test showed that the mathematical connection ability of the control class students and the experimental class had a Sig $=0.315>$ of $\alpha=$ 0.05 value then Ho was accepted; in other words, the two data had homogeneous variances. Furthermore, the two-difference test on averages used the Independent Sample T-Test.

Table 5

Independent Samples T-Test

\begin{tabular}{|c|c|c|c|c|c|c|c|c|}
\hline & & \multicolumn{7}{|c|}{ t-test for Equality of Means } \\
\hline & & \multirow[t]{3}{*}{$\bar{T}$} & \multirow[t]{3}{*}{$\mathrm{df}$} & \multirow{3}{*}{$\begin{array}{l}\text { Sig. } \\
\text { (2-tailed) }\end{array}$} & \multirow{3}{*}{$\begin{array}{l}\text { Mean } \\
\text { Difference }\end{array}$} & \multirow{3}{*}{$\begin{array}{l}\text { Std. } \quad \mathrm{Er} \\
\text { Difference }\end{array}$} & r95\% & Confidence \\
\hline & & & & & & & $\begin{array}{l}\text { Interval } \\
\text { Differer }\end{array}$ & $e^{\text {of the }}$ \\
\hline & & & & & & & Lower & Upper \\
\hline & $\begin{array}{l}\text { Equal } \\
\text { variances } \\
\text { assumed }\end{array}$ & 10.0298 & 71 & .00 & .33161 & .322 & .26741 & .39582 \\
\hline Pretest & $\begin{array}{l}\text { Equal } \\
\text { variances } \\
\text { not } \\
\text { assumed }\end{array}$ & 10.261 & 65.54 & .00 & .33161 & .032 & .26708 & .39615 \\
\hline
\end{tabular}

Sig (2-tailed) value was $0.00<\alpha=0.05$, meaning that Ho was rejected. Thus it was concluded that the increase in mathematical connection ability of students who get learning with the CORE learning model was better than the increase in the mathematical connection ability of students using the expository method. 
Table 6

Statistics Test for Correlations of Mathematical Communication Abilities, Mathematical Connection and Mathematical Dispositions in Experimental Class

\begin{tabular}{|c|c|c|c|c|c|}
\hline \multicolumn{6}{|l|}{ Correlations } \\
\hline & & & Communication & Connection & \\
\hline & & & Experiments & Experiments & Disposition \\
\hline \multirow[t]{9}{*}{$\begin{array}{l}\text { Spearman's } \\
\text { rho }\end{array}$} & \multirow[t]{3}{*}{$\begin{array}{l}\text { Communication } \\
\text { Experiments }\end{array}$} & $\begin{array}{l}\text { Correlation } \\
\text { Coefficient }\end{array}$ & 1.000 & $.650^{* *}$ & $.664^{* * *}$ \\
\hline & & Sig. (2-tailed) & . & .000 & .000 \\
\hline & & $\mathrm{N}$ & 37 & 37 & 37 \\
\hline & \multirow[t]{3}{*}{$\begin{array}{l}\text { Connection } \\
\text { Experiments }\end{array}$} & $\begin{array}{l}\text { Correlation } \\
\text { Coefficient }\end{array}$ & $.650^{* *}$ & 1.000 & $.720^{* *}$ \\
\hline & & Sig. (2-tailed) & .000 & & .000 \\
\hline & & $\mathrm{N}$ & 37 & 37 & 37 \\
\hline & \multirow[t]{3}{*}{ Disposition } & $\begin{array}{l}\text { Correlation } \\
\text { Coefficient } \\
\end{array}$ & $.664^{* *}$ & $.720^{* *}$ & 1.000 \\
\hline & & Sig. (2-tailed) & .000 & .000 & \\
\hline & & $\mathrm{N}$ & 37 & 37 & 37 \\
\hline
\end{tabular}

**. Correlation is significant at the 0.01 level (2-tailed).

Based on the data in table 6 for the experimental class, all results showed that the value of $0.00<0.05$ which meant that there was a significant correlation between communication skills and connection abilities, between communication and disposition, and between connection and mathematical disposition, in classes that had the CORE model.

\section{DISCUSSION}

\section{Increased Mathematical Communication Ability}

The purpose of this study was to determine the increase in mathematical communication skills of students using the CORE learning model and students who received learning using the expository method. The initial test analysis showed that there were no significant differences in the class that received learning with the CORE learning model and the class that received learning with the expository method. After learning with the CORE learning model, the mathematical communication skills of students who got learning with the CORE learning model differed significantly from students who learned by the expository method. Students who learned with the CORE learning models had higher increases than students who learned with the expository method. Thus, the CORE learning model provided a meaningful role in improving students' mathematical communication skills when compared to learning by the expository method.

This is in line with the results of research by Hariyanto (2016), concluding that the CORE learning model significantly influenced mathematical communication skills when compared to conventional learning. CORE provides an interaction experience between students. Yang, Chang, Cheng \& Chan (2015) stated that mathematical communication emphasizes people's interaction and exchange of mathematical ideas, which are 
important abilities for students to express their respective mathematical concepts, understand and evaluate similarities and mathematical thinking from other students.

\section{Increased Mathematical Connection Ability}

The next study aims to analyze the increase in mathematical connection skills in trigonometry material, especially about the rules of sine, cosine and triangles using the CORE learning model and students who get the expository learning model. The initial analysis before being given a different treatment, showed that there was no difference in the mathematical connection ability of students who received learning with the CORE learning model and students who received expository learning. However, after being given different treatments, results showed that learning using the CORE learning model could improve students' mathematical connection skills in trigonometry material. This is in line with the research conducted by Azizah (2012) reporting that the mathematical connection ability of students who use CORE model learning with constructivism approaches is better than students who use expository model learning and an increase in the value of mathematical connection abilities included in the medium category. In addition, the results of this study indicate that increasing the mathematical connection ability of students who get learning with the CORE learning model is better than the increase in the math connection skills of students who learn by the expository method.

However, individually there were still some students who experience a decrease in grades obtained. After conducting interviews with these students, there were several causes that were raised. Among them were students suggesting difficulties when understanding the questions given. The given story questions were less identifiable. So there were some wrong problems done. For example, choosing between using the sine or cosine formula. Zengin (2019) reports that learning is based on intra-mathematical connections and extra-mathematical connections, allowing students to maintain their knowledge, so that they gain various connection experiences. CORE learning also provides connectivity experience in mathematics. On the other hand, Dolores-Flores, Rivera-Lopez \& Garcia (2018) mention that procedural and conceptual knowledge plays an important role in mathematical connections, both of which are positively correlated. This correlation can be developed through instruction and improve their mathematical understanding. They strongly suggest the importance of mathematical connections to improve understanding of the level of change.

\section{Mathematical Disposition}

Students' mathematical disposition to mathematics arises when students complete mathematical tasks carried out with confidence, responsibility, diligence, never give up, feel challenged, have the willingness to look for other ways and reflect on the ways of thinking that has been done.

The results showed that the mathematical disposition of students who received the CORE learning model was higher compared to the expository ones. This is in line with 
the study of Mahmuzah, Ikhsan \& Yusrizal (2014) that the overall increase in mathematical disposition of students who had learning with the problem posing method was better than students with conventional learning methods.

Mathematical disposition is very dependent on intrinsic and extrinsic factors in each individual. Therefore, we need a strong desire from students to fulfill all disposition indicators. The teacher has a very important role in fostering students' mathematical dispositions, the encouragement given by the teacher will lead to a positive attitude towards what students learn. Carr (Maxwell, 2001) states that dispositions differ from knowledge and skills, but dispositions can arise from the results of knowledge and skills. Furthermore, Carr (Maxwell, 2001) adds that students who understand a concept meaningfully do not have to have a comfortable feeling when learning. So students who have high mathematical abilities do not necessarily have high dispositions and vice versa. There was no significant difference between students' mathematical dispositions in the CORE learning class and expository learning classes.

Based on data analysis, the indicators of mathematical disposition are flexible in mathematics learning which include finding mathematical ideas and trying various alternative solutions to mathematical problems. However, students are still relatively low on persistent and strong indicators in completing math assignments. That happens because students are still fixated on the example given by the teacher or just an example on the worksheet. In general, students can solve mathematical problems if problems have been studied by them, but when they find new problems that are different from the example, students tend to have difficulty solving problems especially if the problem is in the form of problem solving. The perseverance and tenacity of students in the struggle to solve mathematical problems is still lacking, they often tend to give up and despair when they face difficult problems. Kusmaryono, Suyitno, Dwijanto \& Dwidayati (2018) stated that behavior, attitudes and awareness of teachers about students mathematical dispositions are important factors that influence students' mathematical dispositions and to assess the effectiveness and quality of mathematics teachers

However, in general students' mathematical dispositions tend to be positive. Students' confidence in solving math problems has begun to grow. Based on the results of interviews with the use of the CORE model, it can increase students' confidence in solving mathematical problems and communicating them in front of the class. With mutual respect in learning, will give effect to students in conducting positive learning in the classroom. Students will feel interested and be positive about mathematics. Learning to use the CORE model increases students' knowledge about the usefulness of mathematics in other sciences or even in everyday life. This attitude results in students being motivated to learn mathematics.

\section{Correlation of Mathematical Connection, Communication, and Disposition}

The results of the study indicate that there is a correlation between communication skills and connection abilities, between communication and disposition and between connection and mathematical disposition in classes that use the CORE model. This can 
be seen from the test results of students who show when the results of communication skills are high then the result of the connection ability is also high, or vice versa. This is contrary to the opinion expressed by Bernard (2015) that there is no association between students' mathematical communication skills with dispositions. This shows that when the results of communication capabilities are high, the disposition is not necessarily also high. But there are opinions that are in line with this research, namely the opinion of Sumarni (2016) that there is an association between mathematical connection skills and self-regulated learning. In line with the opinion of Fajri \& Ikhsan (2013) who concluded that there was a correlation between the ability of connections and mathematical communication of students both in the experimental class with a range of correlation strengths in the strong correlation category. Supporting research was also put forward by Ahmad (2011), who stated this research has determined the interrelationship between each variable which is self-concept and response strategies and their relationship with academic achievement, which means that this research has succeeded in determining the reciprocal relationship between each variable is a self-concept and response strategy and their relationship with academic achievement

\section{CONCLUSION}

Conclusions obtained include: 1) CORE learning model can improve students' mathematical communication skills; 2) CORE learning model can improve students' mathematical connection skills; 3 ) the mathematical communication for topic $\mathrm{I}=76.46$; topic $\mathrm{II}=70.98$; topic $\mathrm{III}=72.87$; post-test $=74.26$; and the mathematical connection was topic $\mathrm{I}=80,07$; topic $\mathrm{II}=79,98$; topic $\mathrm{III}=75,78$; post-test=80,27; 4) improvement of mathematical communication skills of students who learned with the CORE model was better than students who used the expository model; 5) improvement of mathematical connection skills of students who learned with the CORE model was better than students who used the expository model; 6) mathematical dispositions of students who learned with the CORE model were higher than those used expository learning as well; 7) there were correlations between communication skills and connection abilities, between communication and disposition, and between connection and mathematical disposition in class used the CORE model. 


\section{REFERENCES}

Ahmad, J. (2011). The Relationship between self-concept and response in university Putra Malaysia towards student's academic achievement among students leaders. International Journal of Instruction, 4(2), 23-38.

Azizah. L. (2012). Pengembangan perangkat pembelajaran model CORE bernuansa konstruktivistik untuk meningkatkan kemampuan koneksi matematis siswa. Unnes Journal of Mathematics Education Reseach, 1(2), 100-105.

Bernard, M. (2015). Meningkatkan kemampuan komunikasi dan penalaran serta disposisi matematik siswa SMK dengan pendekatan konstekstual melalui game adobe flash CS 4.0. Jurnal Ilmiah Program Studi Matematika STKIP Siliwangi, 4(2), 197-222. doi: 10.22460/infinity.v4i2.84.

Brewer, D. R. (2011). The dispositions improvement process. Int. J. of Ins., 4(2), 51-68.

Calfee, R. C. (2010). Textbooks for learning; Nurturing children's minds. Malden, MA: The University of Chicago Press. American Journal of Education, 107/4, 332-338.

Depdiknas. (2008). Matematika (materi pelatihan terintegrasi). Jakarta: Departemen Pendidikan Nasional.

Dolores-Flores, C., Rivera-Lopez, M. I. \& Garcia-Garcia, J. (2018). Exploring mathematical connections of pre-university students through tasks involving rates of change. International Journal of Mathematical Education in Science and Technology, 50(3), 369-389. doi:10.1080/0020739X.2018.1507050.

Fajri, N., \& Ikhsan, M. (2013). Menggunakan pendekatan contextual, Jurnal Unsyiah. $6,149-161$.

Fisher, D., Yaniawati, P., \& Kusumah, Y. (2017). The use of the CORE model by metacognitive skill approach in developing characters of junior high school students. AIP Conference Proceedings. 1868, 050010, doi:10.1063/1.4995137.

Gabriel, F., Signolet, J., \& Westwell, M. (2017). A machine learning approach to investigating the effects of mathematics dispositions on mathematical literacy. Int. J. of Res. \& Method in Edu., 41(3), 306-327. doi:10.1080/1743727X.2017.1301916.

Hariyanto. (2016). Application of the CORE model in mathematics learning to improve students' mathematical communication capabilities. Gammath Journal, 1(2), 33-40.

Humaira, F. A. (2014) Penerapan model pembelajaran core pada pembelajaran matematika siswa kelas X SMAN 9 padang. Journal Pendidikan Matematika Universitas Negeri Padang. 3(1), 31-37

Indrawan, R., \& dan Yaniawati, P. (2014). metodelogi penelitian kuantitatif, kualitatif dan campuran untuk manajemen pembangunan dan pendidikan. Bandung: Replika 
Aditama.

National Research Council. (2001). Adding it up: Helping children learn mathematics. Washington, DC: The National Academies Press. doi:10.17226/9822.

Kosko, K. W., \& Gao, Y. (2015). Mathematical communication in state standards before the common core. Educational Policy, 31(3), 275-302. doi: $10.1177 / 0895904815595723$.

Kusmaryono, I., Suyitno, H., Dwijanto, D., \& Dwidayati, N. (2019). The effect of mathematical disposition on mathematical power formation: Review of dispositional mental functions. International Journal of Instruction, 12(1), 343-356

Mahmuzah, R., Ikhsan, M., \& Yusrizal. (2014). Peningkatan kemampuan berpikir kritis dan disposisi matematis siswa SMP dengan menggunakan pendekatan problem posing. Jurnal Didaktik Matematika, 1(2), 43-53.

Maxwell, K. (2001). Positive learning dispositions in mathematics. ACE Papers, 11, 30$38 . \quad$ Retrieved from. http://www.educatio.auckland.ac.nz/uoa/fms/default/education/docs/word/resea/foed_pa per/issue11/ACE_Paper_3_Issue_11.doc.

NCTM (2000). Principles and standards for school mathematics. Reston, VA: NCTM

Pearson Education. (2000). Mathematical disposition. Retrieved from http://www.teachervision.fen.com/math/ teacher-training/55328.html?for_printing=1.

Pekrun, R., Goetz, T., Titz, W., \& Perry, P. R. (2010). Academic emotions in students' self-regulated learning and achievement: A program of qualitative and quantitative research. Educational Psychologist, 37(2), 91-105. doi: 10.1207/S15326985EP3702_4.

Risnawati, Khairinnisa, S., \& Darwis, A. H. (2018). Developing CORE model-based worksheet with recitation task to facilitate students' mathematical communication skills in linear algebra course. IOP Conf. Series Journal of Physics, 948(1), 012052. doi: $10.1088 / 1742-6596 / 948 / 1 / 012052$

Roshandel, J. (2018). L2 Motivational self-system and self-efficacy: A quantitative survey-based study. Int. J. of Ins., 11(1), 329-344. doi: 10.12973/iji.2018.11123a.

Sumarmo, U. (2010). Berpikir Dan Disposisi Matematik: Apa, Mengapa, dan bagaimana dikembangkan pada peserta didik. Bandung: FPMIPA UPI.

Sumarmo, U. (February, 2012). Pendidikan karakter serta pengembangan berpikir disposisi matematika dalam pembelajaran matematika, Makalah Disajikan pada Seminar Pendidikan Matematika, NTT Tanggal. 
Sumarni, E. (2016). Tinjauan Korelasi antara Kemampuan Koneksi Matematis dan SRL Matematika Siswa yang Pembelajarannya Melalui Learning Cycle 5E. JES-MAT, 2(1), 83-98. doi: 10.25134/jes-mat.v2i1.283.

Yang, E. F. Y., Chang, B., Cheng, H. N. H., \& Chan, T. W. (2015). Improving pupils' mathematical communication abilities through computer-supported reciprocal peer tutoring. Educational Technology \& Society, 19(3), 157-169.

Yaniawati, R. P., Kartasasmita, B. G, Kariadinata, R., \& Sari, E. (2017). Accelerated learning method using Edmodo to increase students' mathematical connection and selfregulated learning. In Proceedings of the 2017 International Conference on Education and Multimedia (pp. 53-57). Singapore: ACM.

Zengin, Y. (2019). Development of mathematical connection skills in dynamic learning environment. Edu. and Inf. Tec., 24(3), 2175-2194. doi: 10.1007/s10639-019-09870-x. 